на обучения для конкретного слушателя. Выводы. В реализации такого адаптивного оценивания обеспечивается дифференциация обучения. Такая форма работы повышает мотивацию студентов, нивелирует негативные эмоциональные моменты (формулу (неуспеха») в обучении, позволяет иностранным студентам работать в своём индивидуальном темпе, добиваясь положительных результатов в обучении.

Ключевые слова: Online Test Pad, ИКТ, диагностика знаний, критериально-ориентированное тестирование, нормативно-ориентированное тестирование, корректирующее, диагностическое, иностранные студенты, язык.

Galyna Ye. PRISOVSKA,

Candidate of Philology Sciences (PhD), associate professor, Head of the Department of Linguodidactics, Odessa National Polytechnic University, Educational Institute of Foreign Citizens Training; 1 Shevchenko avenue, Odessa, 65044, Ukraine; tel.: +38 0964944414; e-mail: galyna2005@gmail.com; ORCID ID: 0000-0001-9488-3825

Olena V. IVANOVA,

Senior lecturer of the Department of Linguodidactics, Odessa National Polytechnic University, Educational Institute of Foreign Citizens Training; 1 Shevchenko avenue, Odessa, 65044, Ukraine; tel.: +38 0632997937; e-mail: iev@opu.ua; ORCID ID: 0000-0001-7616-8502

\title{
CONTROL OF KNOWLEDGE OF FOREIGN STUDENTS IN LANGUAGE (ELEMENTAL LEVEL) ASSISTED BY TESTING ON THE ONLINE TEST PAD SITE
}

Summary. The article examines the application of testing on the Online Test Pad platform, identifies two main approaches to the classification of tests: criterion-oriented and regulatory-oriented. The tasks facing the teacher are analyzed, such as diagnostics, correction, control of students' knowledge. Particular attention is given in the article to the objective analysis of student achievements, which allows making a platform. The purpose of this study is to analyze how foreign students studying at the Preparatory faculty of the Odessa National Polytechnic University pass tests of a controlling character online at the Online Test Pad site, to determine the advantages and disadvantages of such control, its features. Within the framework of implementing the scientific topic "Electronic didactic tools as a basic component of the educational environment for language training of foreign citizens", the Department of Linguistics didactics of ONPU continues the implementation of projects on creation of new modern didactic materials to ensure effective control of knowledge using electronic resources in the discipline "Language» stage of training. Having analyzed all the advantages and disadvantages of designers available on the network, and considering the purpose and objectives - controlling vocabulary testing of foreign students studying the language at the Preparatory faculty, we have chosen the Online Test Pad online platform. The Online Test Pad platform, as stated on the site, is free, easy to use and quick to set up. When tested using the online platform, the assessment of success or failure takes on a new quality - it is an indicator of the student's level of knowledge, which at the same time leads to the development of a further unique learning plan for a particular listener. Conclusion. Differentiation of learning is ensured in implementing such an adaptive assessment. This form of the work increases students' motivation, eliminates negative emotional moments (formula of (failure») in studying, allows foreign students to work at their individual pace, achieving positive results in learning.

Key words: Online Test Pad, ICT, knowledge diagnostics, criterion-oriented testing, normative-oriented testing, corrective, diagnostic, language, foreign students.

Статтю отримано 18.10.2019 p.

http://dx.doi.org/10.18524/2307-4558.2019.32.187648

УДК 811.161.2'234'243:371.38

TRUBA Hanna Mykolaivna,

Candidate of Philology, Associate Professor of the Applied Linguistics Department, Odessa I. I. Mechnikov National University; 24/26 Frantsuzskiy blvd., Odessa, 65058, Ukraine; tel.: +38 048 7762277;

e-mail: 3182009060@ukr.net; ORCID ID: 0000-0001-9944-0476

\section{NEUROPHYSIOLOGY AND NEUROLINGUISTICS BACKGROUND OF THE STUDING UKRAINIAN AS FOREIGN LANGUAGE}

Summary. After adopting the new (2019) language law the learning of Ukrainian as the foreign is not only the matter of desire or taste but also it is necessary for getting citizenship. So it is set up new challenges for teachers. The purpose of the article is to show the interconnection of neurophysiology and neurolinguistics with methods of teaching. The object of this article is to describe the usage of neurolinguistics as a basis for the creation of modern foreign language teaching techniques. The subject of the article is to study the role of neurophysiology in the development of special techniques and the creation of a theoretical basis for the creation of modern methods of learning Ukrainian as a foreign language. There are used the descriptive and analytical methods. The results of this research are working-out the new way of teaching 
the Ukrainian language for foreigners and working-out the ways of creating text books. The actuality of this research is the attempting of making new approach and effort to the general approach for studying foreign language according to the reality of students' brain work. The practical value of the research is the possibility of using this results for investigation and optimization the studying the linguistics phenomena, for optimization of studying process for linguists, for essential understanding of fundamental linguistics processes, to form new teaching plans according to the new reality of new ways of thinking and brain working.

Key words: brain work, neurophysiology, neurolinguistics, methods of teaching, Ukrainian as foreign language.

Problem-setting. Human interest to the work of the brain and desire of ways to optimize it is unstoppable: the interests to the studying of memory and thought processes features - is constantly growing, namely the question of improving teaching methods in this context. Scientific approaches to the study and definition of the brain work category are being developed actively in such modern fields as psychology (considers thinking as thought processes that underlie cognition, examines types of individual thinking of the individual and processes of perception and assimilation of new material), philosophy (defines understanding itself as thinking, makes an attempt to look at the process of thinking (from the outside»), logic (systematizes and classifies stages of thinking), sociology (explains the dependence of the level of thinking on the degree of development of society in general and social development of the individual in this society, the collective conscious, institutions and belonging to a particular cultural community), physiology (describes the basic physiological stages of the process of thinking occurring at the cellular level), cybernetics (considers thinking as an information process of receiving and processing information), neurophysiology of perception learning as a purely physical process at the level of our body $[1, p .14]$. As we can notice the brain work categories are extremely important so it is impossible to reject the peculiarities of physiological perception in the process of teaching.

The relevance of the issue of studying the Ukrainian language as a foreign language consists of several aspects: objective aspect (in 2019 the new Language Law was introduced, which significantly expanded the boundaries of compulsory usage of the Ukrainian language that's why the necessity of its studying increased greatly), purely linguistic aspect (language is constantly updated, new rules are being developed, learning process - continuous and infinite), neurolinguisticsaspect (under the influence of technological factors changes the way of perception of information, changes the brain work, which we can't ignore during the teaching process) [6].

The problem of neurolinguistics now arises much more broadly, because if earlier neurolinguistic approaches were understood only from the point of view of aphasia correction, at the beginning of the 21 st century we can speak about the application of special knowledge in neurolinguistics, neurophysiology, psychology, suggestiology in work [2].

Task-setting. The object of this research is to investigate the usage of neurolinguistics as a basis for the creation of modern foreign language teaching techniques. And the subject is to study the role of neurophysiology in the development of special techniques and the creation of a theoretical basis for the creation of modern methods of learning Ukrainian as a foreign language. The purpose of our study is to identify the features of neurophysiological perception of information and linguistic expression of thinking processes. Therefore, it is necessary to consider the problem of brain work in the context of learning foreign languages in general and studying of the Ukrainian language as an integral part of this process. After all, this is a key issue when concluding a program that will maximize its impact [1, p. $7 ; 6]$.

The basic material presentation. With the development of science, more and more attention is paid to the issues that underlie philosophy and linguistics: the analysis of speech phrases, problems of meaning, the study of speech phenomena and related properties of different brain departments, which, in turn, can be characterized as thinking, which is part of the mental processes that carry consciousness $[1$, p. $17 ; 7$, p. 9].

At the present stage of society's development, the old techniques of influence, presentation and studying in general are not effective under the influence of the development of modern information technologies. But the general stages of brain work have not remained unchanged, so a strategy to optimize the swim when learning a foreign language should be developed.

Thus, at the general level, the physiology of thinking is studied as a certain function of the brain, the mechanisms of which correspond to neurons of the cerebral cortex, whose various areas perform specific functions: the temporal lobe is responsible for memory processes, the frontal lobe - for making plans, choosing a goal, making a decision, associative fields of temporal lobe, frontal and occipital lobes - for language use [1, p. 18].

There is a special area of scientific knowledge - psychophysiology, which studies the physiological foundations of human mental activity, studies the behavior and inner world of the individual through the prism of physiological changes [6]. And the dissemination of knowledge beyond the narrow circle of neurophysiologists is extremely important: it allows to change the misconception of "folk" psychophysiology to the real knowledge that is in the arsenal of science, and pedagogy in particular, and especially the aspect of foreign language learning. This knowledge forms the necessary basis for the formation of conscious ideas about the healthy lifestyle of each person [6]. 
The term "physiological psychology" was introduced by W. Wundt in the late $19^{\text {th }}$ century, and the term psychological physiology by A. Luria to highlight a systematic approach to the study of mental processes.

This science is based on Anokhin's theory of functional systems. The other science of neuropsychology was formed on the border of several disciplines (neurosurgeons, psychologists, physiologists) and was based on the analysis of the effects of local brain damage. A significant contribution to the development of its basic principles made A. Luria, who formed the theory of systematic dynamic localization of mental processes. The emergence of tomographic studies extends the possibility of non-invasive analysis of the human brain for norms and pathology, thereby bringing the task of psychophysiology and neuropsychology closer [6].

Therefore, if we approach the process of learning a foreign language, as a purely physiological and mental process, then you should rely on knowledge of the autonomic system and its sympathetic and parasympathetic departments. Thus, Walter Cannon emphasized that the sympathetic nervous system expands the range of endurance of the organism during extreme conditions, and the functioning of the organism at the base provides parasympathetic system. In other words, the sympathetic system ignites and activates, and the parasympathetic system inhibits and soothes [6]. The peculiarities of functioning of the autonomic nervous system are the reciprocal interaction of its components (parasympathetic and sympathetic systems), and the parallel existence of several ways of providing functions, that is, the absence of a single center of human character and character.

Therefore, based on basic knowledge of neurophysiology, basic criteria have been worked out that influence the brain's function in the perception of information, including the study of a foreign language $[1 ; 6]$ :

- materiality - this principle is that the summary characteristics of any mental process can be described, measured only in terms and relations of external objects, the physical existence of which is its meaning;

- subjectivity - is that in the picture of the mental process there are hidden changes of the organ-carrier that implements this process, and the final, final parameters can't be formulated in their own physiological language of those quantities and phenomena that can be found in the human brain;

- sensory inaccessibility - is characterized by the fact that psychic processes are inaccessible to direct sensory observation: to its carrier-subject, a mental process (perception or thought) opens the properties of the object, leaving hidden changes in the brain or human;

- spontaneous activity - unlike the preceding characteristics, determines not the direct relation of an object or its direct-substrate to the brain, and its expression in a behavioral act, in an external action, an inducement directed by the mental process.

Conclusions. Thus, only the knowledge of the teacher of physiological features of the student can effectively build the process, and for the compiler of the textbooks should be different effects. Applying the terms of pedagogy, the sympathetic system is responsible for control work, tests, active emotional perception, and parasympathetic - allows you to focus on one issue and get into its essence, without paying attention to minor or external stimuli. In other words, we cannot disregard these facts when compiling programs and textbooks on the subject "Ukrainian as a Foreign Language». Namely, emotional tasks should alternate with monotonous grammar exercises. And in order to make the cimperceptible brain process» (noticeable," you have to split the material, and after each small block there should be a test work with the number of points, so that everyone who studies can clearly see the result of their brain activity. And this will certainly raise the level of motivation.

The practical value of this study is that its results and conclusions can be used in the course of lecturing and conducting seminars on the methods of foreign languages and neurolinguistics, philosophy (in the context of communication and thinking and perception of native and foreign languages).

\section{References $I$}

1. Асонова Г. А. Роль нейролингвистических исследований для лингвистики и методики преподавания иностранных языков в области формирования речевого общения. Международный науино-исследовательский журнал. Филологические науки. Екатеринбург : Соколова М. В., 2016. Вып. 12 (54). Ч. 2. С. 11-13. D0I: https://doi. org/10.18454/IRJ. 2016.54.080.

2. Бехтерева Н. П. Магия мозга и лабиринты жизни. Москва : АCT, 2007. 400 с.

3. Веккер Л. М. Психика и реальность : единая теория психических процессов. Москва : Смысл, 1998. 85 с.

4. Коротяев А. И., Бабичев С. А. Роль генетической и умственной систем информации в возникновении и развитии жизни на земле. Нальчик : Эльбрус, 2009. 236 с.

5. Кубрякова Е. С. Начальные этапы становления когнитивизма : лингвистика - психология - когнитивная наука. Вопросы языкознания. Москва, 1994. № 4. С. 34-47.

6. Николаева Е. И. Психофизиология. Психологическая физиология с основами физиологической психологии. Москва : ПЕР СЭ, 2017.624 c.

7. Федотова Е. Е. Языковая репрезентация когнитивно-ментальной сферы (мыслительная активность» в произведениях Ф. М. Достоевского : дис. ... канд. филол. наук : 10.02.19. Краснодар, 2017. 211 с. 
References $I I$

1. Asonova, G. A. (2016), "The role of neurolinguistic studies for linguistics and methods of teaching foreign languages in the field of the formation of verbal communication", International Research Journal. Philological sciences ["Rol' neyrolingvisticheskikh issledovaniy dlya lingvistiki I metodiki prepodavaniya inostrannykh yazykov v oblasti formirovaniya rechevogo obshcheniya", Mezhdunarodnyy nauchno-issledovatel'skiy zhurnal. Filologicheskiye nauki], Sokolova, M. V. (ed.), Yekaterinburg, Issue 12 (54), part 2, pp. 11-13. DOI : https://doi.org/10.18454/ IRJ. 2016.54.080 $400 \mathrm{p}$

2. Bekhtereva, N. P. (2007), Brain magic and the labyrinths of life [Magiya mozga i labirinty zhizni], AST, Moscow,

3. Vekker, L. M. (1998), Psyche and reality : a unified theory of mental processes [Psikhika i real'nost': yedinaya teoriya psikhicheskikh protsessov], Smysl, Moscow, $85 \mathrm{p}$.

4. Korotyaev, A. I., Babichev, S. A. (2009), The role of genetic and mental information systems in the emergence and development of life on earth [Rol' geneticheskoy $i$ umstvennoy sistem informatsii $v$ vozniknovenii $i$ razvitii zhizni na zemle], Elbrus, Nalchik, 236 p.

5. Kubryakova, E. S. (1994), "The initial stages of the formation of cognitivism : linguistics - psychology - cognitive science», Topics in the study of language [ "Nachal'nyye etapy stanovleniya kognitivizma : lingvistika - psikhologiya kognitivnaya nauka», Voprosy yazykoznaniya], Moscow, No. 4, pp. 34-47.

6. Nikolayeva, Ye. I. (2017), Psychophysiology. Psychological physiology with the basics of physiological psychology [Psikhofiziologiya. Psikhologicheskaya fiziologiya s osnovami fiziologicheskoy psikhologii], PER SE, Moscow, $624 \mathrm{p.}$

7. Fedotova, Ye. Ye. (2017), Linguistic representation of the cognitive-mental sphere «mental activity» in the works of F. M. Dostoevsky : Thesis [Yazykovaya reprezentatsiya kognitivno-mental'noy sfery «myslitel'naya aktivnost'» $v$ proizvedeniyakh F. M. Dostoyevskogo : dis. ... kand. filol. nauk : 10.02.19], Krasnodar, $211 \mathrm{p}$.

\section{ТРУБА Ганна Миколаївна,}

кандидат філологічних наук, доцент кафедри прикладної лінгвістики Одеського державного університету імені I. I. Мечникова; Французький бульвар, 24726, м. Одеса, 65058, Україна; тел.: +38 (048) 7762277 ; e-mail: 3182009060@ukr.net; ORCID ID: 0000-0001-9944-0476

\section{НЕЙРОФІВІОЛОГІЯ ТА НЕЙРОЛІНГВІСТИКА ЯК ПІДІРУНТЯ ВИВЧЕННЯ УКРАЇНСЬКОЇ МОВИ ЯК IHOЗEMHOÏ}

Анотація. Після прийняття нового (2019) закону про мову вивчення української мови як іноземної — це не лише питання бажання чи смаку, але й необхідність для отримання громадянства. Таким чином, це ставить перед викладачами нові виклики. Метою статті є показати взаємозв'язок нейрофізіології та нейролінгвістики з методами навчання. Об'єктом вивчення є опис використання нейролінгвістики як основи для створення сучасних методик навчання іноземної мови, а предметом є вивчення ролі нейрофізіології в розробці спеціальних методик і створенні теоретичних засад для використання сучасних методів вивчення української мови як іноземної. У процесі дослідження було використано описовий і аналітичний методи. Результати дослідження - це винахід нового способу навчання української мови та напрацювання процедури та способів творення підручників. Актуальність статті - це спроба розробити новий підхід і поновити загальновідомі підходи до вивчення іноземної мови відповідно до реальної роботи головного мозку в процесі навчання. Практична цінність дослідження полягає у можливості використання цих результатів для дослідження й оптимізації явищ вивчення лінгвістики, для оптимізації навчального процесу, істотного розуміння основних лінгвістичних процесів і формування нових навчальних планів відповідно до нової реальності, яка потребує нових способів мислення та роботи мозку.

Ключові слова: робота мозку, нейрофізіологія, нейролінгвістика, методи навчання, українська мова як іноземна.

\section{ТРУБА Анна Николаевна,}

кандидат филологических наук, доцент кафедры прикладной лингвистики Одесского государственного университета имени И. И. Мечникова; Французский бульвар, 24/26, г. Одесса, 65058, Украина; тел.: 38 (048) 7762277; e-mail: 3182009060@ukr.net; ORCID ID: 0000-0001-9944-0476

\section{НЕЙРОФИЗИОЛОГИЯ И НЕЙРОЛИНГВИСТИКА КАК ОБОСНОВАНИЕ ИЗУЧЕНИЯ УКРАИНСКОГО ЯЗЫКА КАК ИНОСТРАННОГО}

Аннотация. После принятия нового (2019) закона о языке изучение украинского языка как иностранного - это не только желание или дело вкуса, но и необходимость при получении гражданства. Так что это ставит новые задачи перед учителями сейчас. Целью статьи является показать взаимосвязь нейрофизиологии и нейролингвистики с методами обучения и описание использования нейролингвистики в качестве основы для создания современных методик преподавания иностранного языка, а предметом - изучение роли нейрофизиологии в разработке специальных методик и создании теоретической основы для создания современных методов изучения украинского языка как иностранного. При исследовании этого вопроса использовались описательный и аналитические методы. Результатом исследования можно считать разработку нового способа обучения украинскому языку как иностранному и обновление процедуры создания учебников для обучения украинскому языку как иностранному. Актуальность работы заключается в попытке выработать новый подход, усилив общепринятый подход к изучению иностранного языка в соответствии с реальными особенностями работы головного мозга студентов. Практическая ценность исследования заключается в возможности использования этих результатов для исследования и оптимизации изучения лингвистических явлений, оптимизации процесса обучения украинскому языку как иностранному, для понимания основных процессов 
ISSN 2307-4558; ISSN 2414-9489. Мова. 2019. № 32

лингвистики, для формирования новых учебных планов в соответствии с новой реальностью, которая требует новых способов мышления и работы головного мозга.

Ключевые слова: работа мозга, нейрофизиология, нейролингвистика, методика обучения, украинский язык как иностранный.

Статтю отримано 19.10.2019 p. 